University of Nebraska - Lincoln

DigitalCommons@University of Nebraska - Lincoln

Textile Society of America Symposium

Proceedings

$10-2020$

\title{
A Tale of Two Sisters: Invisibility, Marginalization and Renown in a 20th Century Textile Arts Revitalization Movement in New Mexico
}

Suzanne P. MacAulay

Follow this and additional works at: https://digitalcommons.unl.edu/tsaconf

Part of the Art and Materials Conservation Commons, Art Practice Commons, Fashion Design Commons, Fiber, Textile, and Weaving Arts Commons, Fine Arts Commons, and the Museum Studies Commons

This Article is brought to you for free and open access by the Textile Society of America at DigitalCommons@University of Nebraska - Lincoln. It has been accepted for inclusion in Textile Society of America Symposium Proceedings by an authorized administrator of DigitalCommons@University of Nebraska - Lincoln. 


\title{
A Tale of Two Sisters: Invisibility, Marginalization and Renown in a $\mathbf{2 0}^{\text {th }}$ Century Textile Arts Revitalization Movement in New Mexico
}

\author{
Suzanne P MacAulay, PhD \\ smacaula@uccs.edu
}

Honoring the theme of Hidden Stories, my discussion raises questions about the vicissitudes of fame and obscurity of two women relative to artistic creation and textile arts vitalization efforts. This is the story of two Varos sisters, who married two Graves brothers, and lived in rural Carson, New Mexico. In the early 1930s Frances and Sophie Varos Graves along with their extended families repaired Spanish colonial textiles for the Santa Fe market. Around that time, they began to recreate traditional Spanish colonial-type colcha embroideries from re-cycled materials salvaged from nineteenth century colcha fragments. They also raveled yarn from nineteenth century frayed Rio Grande weavings beyond repair. (Much later Carson stitchers continued the practice of re-cycling materials by collecting wool sweaters from garage sales and raveling yarn from them). The "new" colcha embroideries from the 1930s were initially marketed as authentically Spanish Colonial by entrepreneurs such as Elmer Shupe, a local trader and the brother-in-law of Sophie and Frances.
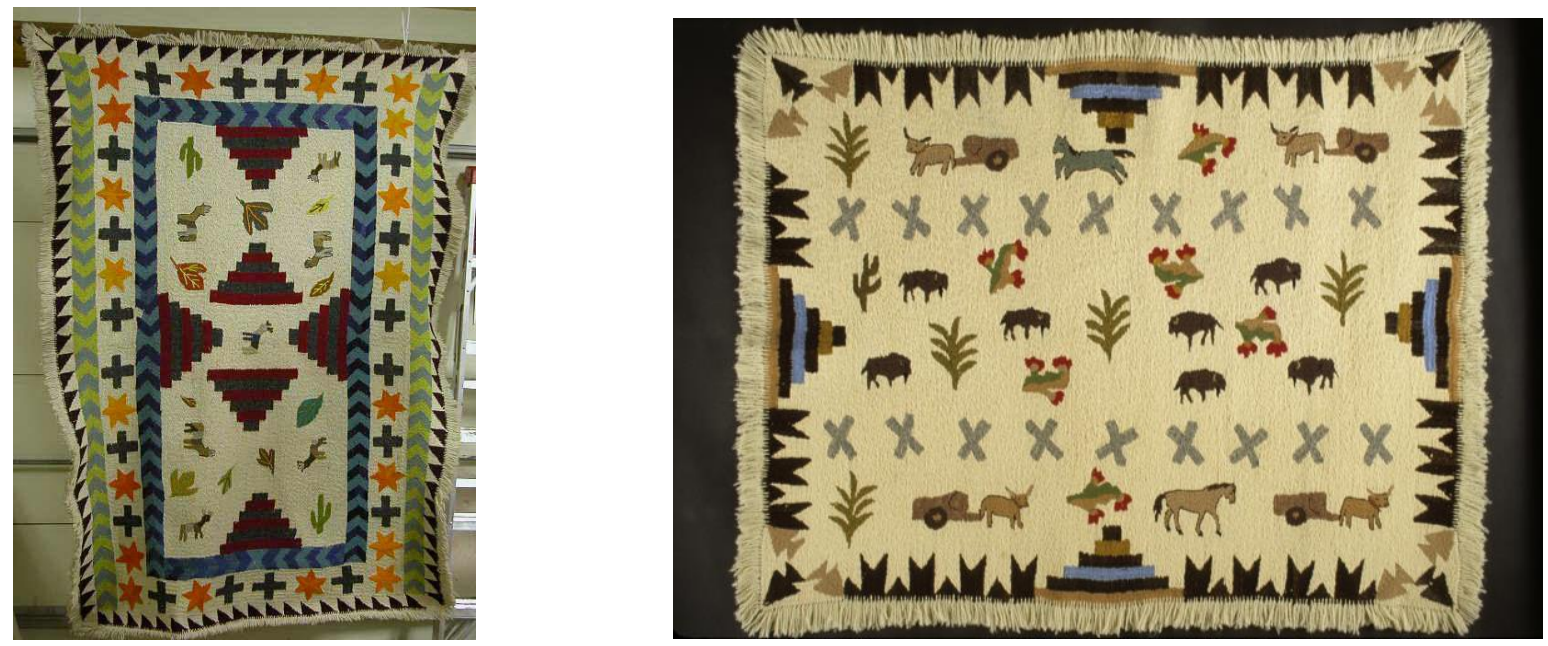

Sophie Graves, "Southwestern Themes,"1988, wool-on-wool colcha embroidery (L). Courtesy the Millicent Rogers Museum, Taos, New Mexico.

Frances Graves, “Blue Pony,” 1990, wool-on-wool colcha embroidery (R). Private Collection. Permission granted.

For over seventy years the Varos sisters continued to create what ultimately became known as Carson colchas, a sub-genre of colcha embroidery within the canon of Southwest Hispanic arts revitalizations. This time period spawned many arts revitalization efforts primarily through WPA economic redevelopment programs and more contemporary efforts in the 1990s. Carson colcha embroideries, however, were really a 'new' version of this genre - a vitalization rather than a revitalization. 
In the beginning Frances and Sophie's early work celebrated romantic visions of the West. Ultimately, they each chose to reproduce non-anachronistic compositions of sparse embroidery fields populated by images of local fauna and flora or, as in Sophie's case, abstract designs. Sophie had an eye for color and pattern. Her skills at dyeing to achieve unusually striking color combinations were perfected over many years of repairing rugs and matching yarns.

In 1994, five years before she died, Frances Graves was awarded the highest honor a folk artist can achieve, a National Endowment for the Arts (NEA) National Heritage Fellowship. Articles and books credit both sisters with originating the Carson colcha embroidery style while their work is often indistinguishable from each other's. Frances Graves was well-known to outsiders, collectors, scholars and curators. Although Sophie also pursued colcha embroidery all her life, she was more private, creating pieces primarily for the market in order to support her family. She rarely received the public or critical attention paid to her sister. The disparity between the creative lives of these sisters raises questions about artistic intention and visibility, promotion and marketing, arts revitalization dynamics, originality, authenticity, aesthetic judgement, and the allure of replication.
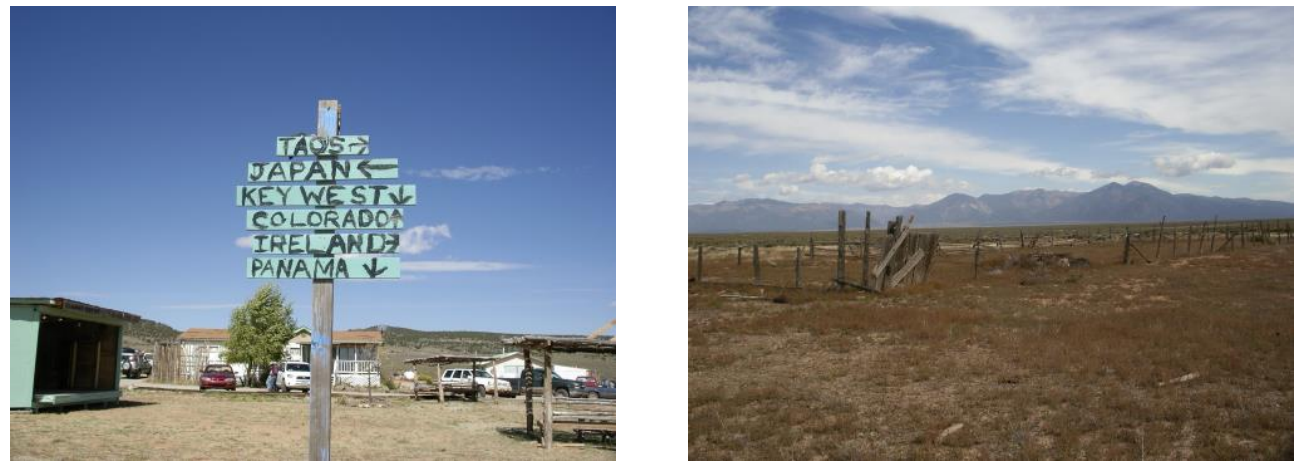

Carson, New Mexico as it looks today. Photos by author.

In the 1930s Carson, New Mexico, was a more populated site than today surrounded by farms and ranches with a local aquifer as a water source. At that time, it was also a site of a thriving cottage industry of textile creation and repair. The Carson enterprise leaves an afterimage of a mixed Anglo-Hispano community, integrated by familial and kin relationships engaged in craftsmanship (i.e., mending, designing and embroidering), superimposed on a seemingly barren and isolated landscape. As Frances once said, "Everybody that was in Carson made colchas men, too...embroidering...yes... anytime...we would embroider by night with gasoline lanterns..." Carson, as a community of stitchers, underscores the importance of art practices and material objects in sustaining bonds between people as individuals and as communities. Lucy Lippard describes the communicative connection binding a group of craftspeople as, "their language was in their hands."2

\footnotetext{
${ }^{1}$ Interview with Frances Varos Graves by Helen Lucero and author, Taos, New Mexico, November $19,1991$.

2 Thoughts inspired by Lucy Lippard, "Busywork: The Real Thing" in Textiles, Community and Controversy edited by Jools Gilson and Nicola Moffat, London: Bloomsbury Visual Arts (2019), 57.
} 
Two colcha embroideries created by Sophie and Frances together from the Millicent Rogers Museum in Taos, New Mexico, collection typify the imagery and compositional format, which dominated the work of the two sisters throughout their careers - actually, throughout their lives since both of them embroidered up until they died. In an interview at the Museum in 1988, Sophie described these two colchas as being made of re-cycled wool in natural tones on wool sabanilla as the ground fabric, "... and there is the... all the brown and some of the white and some of the green... no commercial yarn on that one... that's one of the old ones..." Poignantly, she wistfully finishes her comments, "I never did know I'd see them again." ${ }^{3}$ These embroideries were created when Sophie was seventeen and Frances twenty-one. Sophie had come to Carson to live with Frances and repair rugs. They finished this pair of embroideries before Sophie was married in 1931. Each sister married a Graves brother. Frances married Richard Claude Graves and Sophie married his brother, Frank Graves.
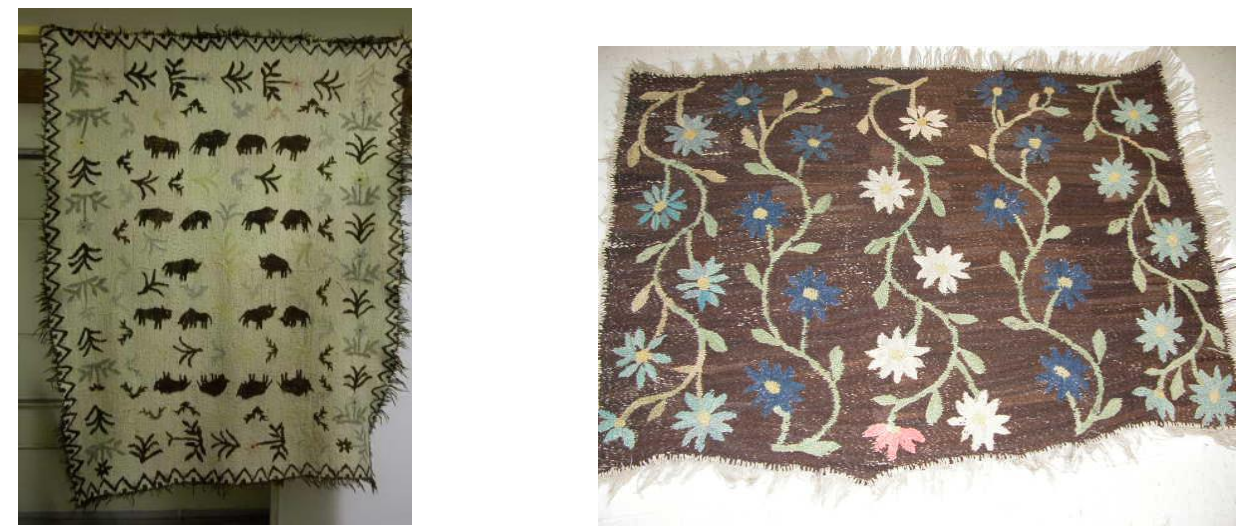

Attributed to Sophie $(L)$ and Frances Graves $(R)$. Both sisters worked on these pieces together. Wool-on-wool colcha
embroideries with localized motifs, c.1931.
Courtesy of Millicent Rogers Museum, Taos, New Mexico.

Hallmarks of Carson-style colcha embroideries are complete coverage of the ground fabric with wool yarn raveled from old blankets plus patches of old sabanilla pieced together comprising the ground fabric. This is also true of these two colcha embroideries where the fringes are composed of recycled nineteenth century handspun wool. Characteristic of eighteenth and nineteenth century traditional wool-on-wool colcha embroideries, their patterns extend from edge to edge to create all-over design fields. The carpet of flowers replicates bands of rinceaux, undulating vines and flowers moving up-and-down the ground fabric - also inspired by local flora. Another technical feature of Carson colcha embroideries is the set of parallel lines of unidirectional stitching progressing from top to bottom moving in only one direction, which gives Carson colchas a rather static appearance. This practice was derived from observing stitches on Spanish Colonial nineteenth century pieces coordinated with the grid-determined weave of ground fabrics.

\footnotetext{
${ }^{3}$ Interview with Sophie Graves, Millicent Rogers Museum, 1988.
} 

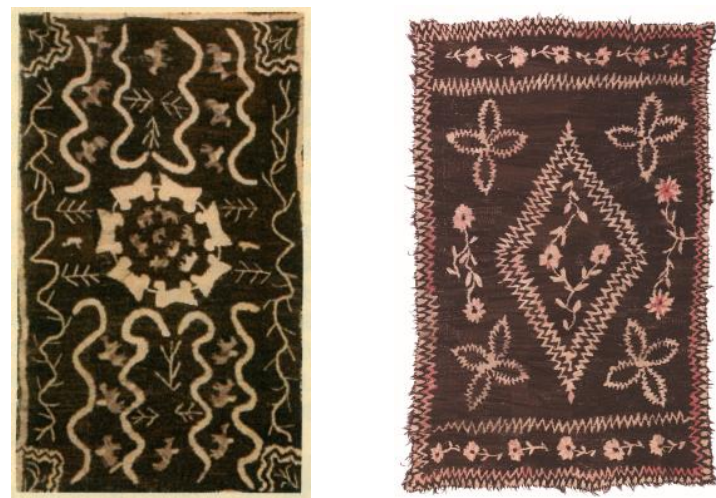

(L) Sophie Graves, “Wagon Train,” wool-on-wool colcha embroidery, Sophie Graves, c. 1930. Museum of Spanish Colonial Arts.

(R) Colch a embroidery, early 1930s with Rio Grande zigzag design elements, possible attribution to Frances Graves. Courtesy of The Albuquerque Museum.

The iconography of Sophie Graves's colcha embroidery on the left depicting a wagon train arranged in a protective circle around livestock with vertical bands of Indians on horseback approaching the wagon train, became a stylistic trademark of the sisters' imagery. Both women continued to replicate singular elements of these compositions such as buffalo, Indians on horseback, wagons, local plants and cacti throughout their lives.

The early 1930s colcha embroidery on the right exemplifies all the characteristics of Carson colcha making during that era. This includes the use of naturally dyed recycled native wool yarns, and the creation of a colonial style composition appropriating Saltillo-style design elements from Rio Grande woven rugs such as the central horizontally elongated diamond with serrated edges and overall frenetic zigzag lines extended to outlines and borders. Each colcha has a prominent central focus inspired by the medallions on Saltillo-style Rio Grande weavings. Navajo rugs and Rio Grande blankets were the main textiles repaired by the Carson stitchers. They knew these designs intimately and utilized shapes from late nineteenth century Navajo pictorial rugs as well. These were primarily animal forms rendered as outlines or silhouettes as seen in Sophie Graves's embroidery, that is, the central cluster of animals surrounded by the wagon train.
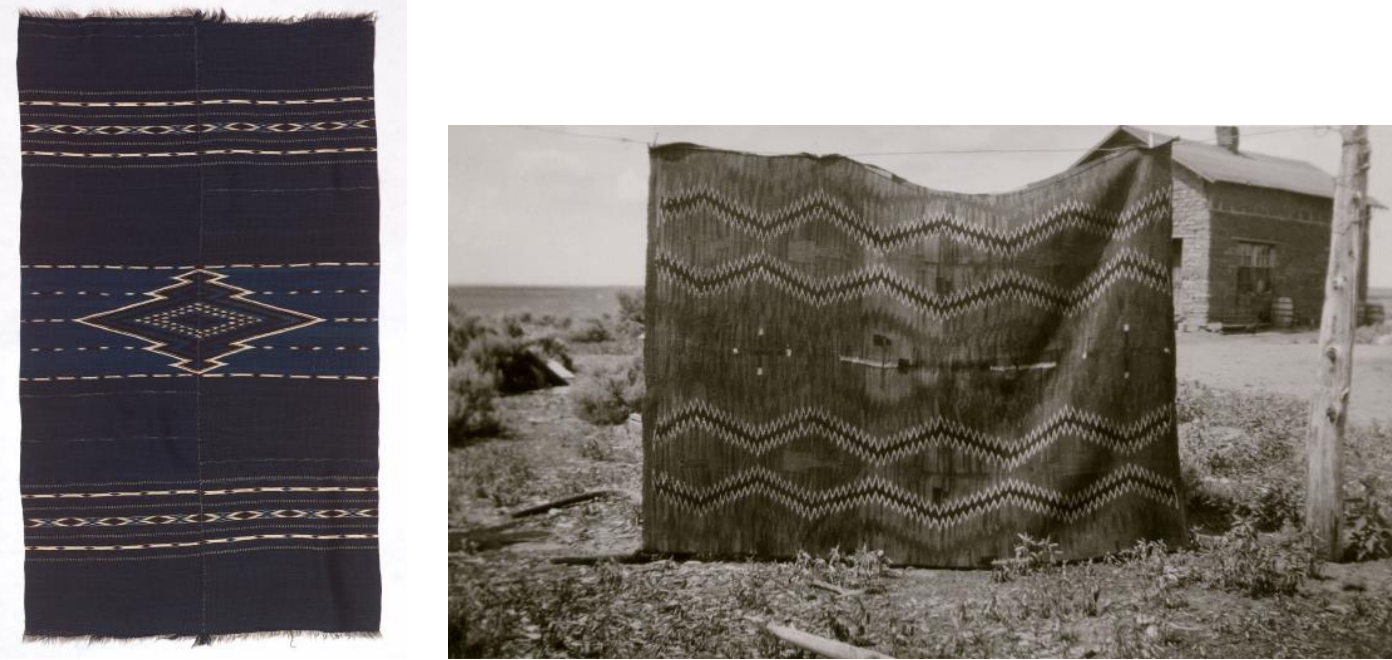
(L) Frazada/Blanket, 1840-1850, Saltillo-style motifs.

Courtesy of The Albuquerque Museum, Albuquerque, New Mexico.

(R) Rio Grande blanket needing repair with Saltillo-style zigzag design motifs, Carson, New Mexico early 1930s, Frances Graves Family Collection. Permission granted.

The Saltillo-style Rio Grande frazada or blanket on the left typifies the kind of blanket repaired in the Carson workshop. The photograph on the right is from Frances Graves's collection showing a large Rio Grande weaving needing repair decorated with characteristic dominant motifs of horizontal serrated zigzags and crosses. For years, Sophie and Frances used and re-used these design elements in their embroidered compositions as part of their standard artistic vocabulary.

Here are two embroideries of identical subjects, composition, color palette, and dimensions. When colcha embroideries such as these individually created by Sophie and Frances, are encountered in museum store rooms, it is difficult to actually tell them apart. Few are labeled with artists' names because they were originally made to be sold as authentic Spanish colonial textiles. Authenticity, would then be compromised by personification rather than maintaining the impression of an anonymous nineteenth-century settler stitcher. The style in each is similar because Sophie and Frances swapped ideas and used each other's embroidery templates. Shapes and forms are the same. So is the placement and composition. This type of imagery was inspired by the stories Claude Graves would tell as a "cowpuncher." The lifestyle of the open range was very familiar to Sophie and Frances, who had grown up listening to tales told by their grandfather, Jose Manuel Varos, of wagon trains, buffalo hunts, breaking horses, skirmishes with tribal Indians and round-ups. The sisters loved developing these narratives in yarn.
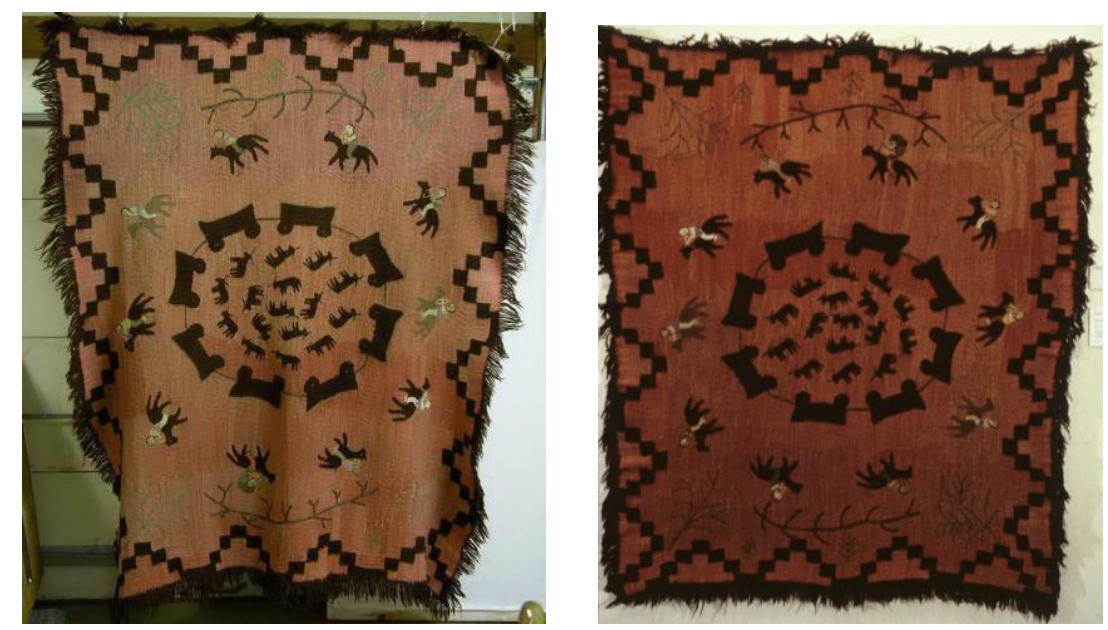

(L) Wagon Train, Sophie Graves, e. 1930s, wool-on-wool colcha embroidery, early 1930s. (R) Frances Graves, "Wagon Train," wool-on-wool colcha embroidery, e. 1930s. Courtesy of the Millicent Rogers Museum, Taos, New Mexico.

The next two embroideries also demonstrate the persistence of "Wild West" imagery in Frances's work, and how she kept optimizing Western themes. The photo of Frances's husband, Claude Graves, also helps to convey a sense of scale of these pieces. Claude's presence in this photo from the early 1960s suggests that collaboration among family members in terms of drawing, inspiring different embroidery subjects, and helping out in various ways continued on 
from the old days in Carson when "everybody made colchas," and the spirit of making stitched the community together.
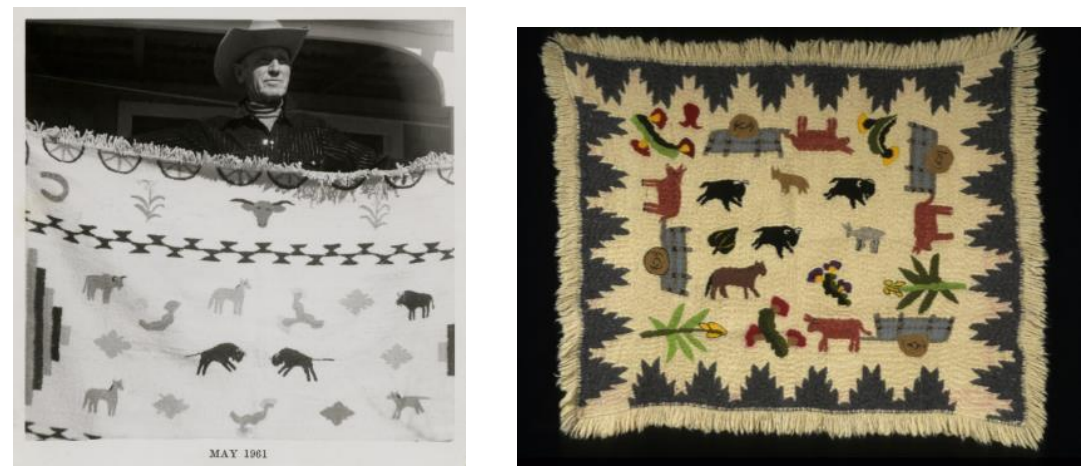

(L) Richard Claude Graves holding a wool-on-wool colcha embroidery by Frances Graves, May 1961. Private collection. Permission granted.

(R) Colcha embroidery, Frances Graves, wool-on-wool colcha embroidery late 1980s. Private collection. Permission granted.

Here is another pair of embroideries by Sophie and Frances using identical imagery, wagon trains with parades of Indians. However, the palettes differ. In 1988, Sophie enthusiastically explained how she achieved her distinct shades of color, "I dyed the blue... and I dyed the green and the yellow, almost all but the brown. That was old, old yarn that I had. I just bought the dye. It's just a commercial dye... You know, we used to get real good ones..."4 Sophie and Frances each put a snake in the lower right central sections of their pieces, which adds some liveliness to the fairly static designs aligned in rows.
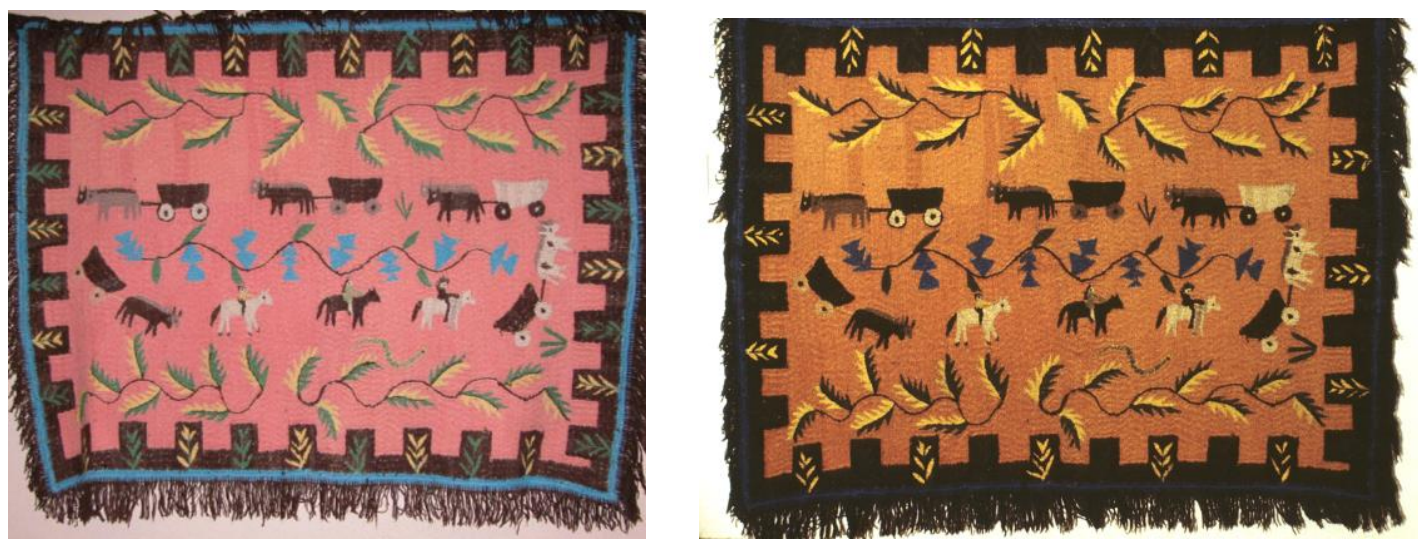

(L) Sophie Graves, Wagon Train and Indians, wool-on-wool colcha embroidery, 1940s-50s.

(R) Frances Graves, Wagon Train and Indians, wool-on-wool colcha embroidery, 1940s-50s. Courtesy of the Millicent Rogers Museum, Taos, New Mexico.

Sophie gave her colcha to Jane Hiatt, owner of a gallery and gift shop in the La Fonda Hotel in Taos, New Mexico. She had moved from Carson to Taos by then, and worked for Hiatt about twenty years. During that time Sophie learned much about the local art scene as well as the

\footnotetext{
${ }^{4}$ Interview with Sophie Graves by Shelby Tisdale, Millicent Rogers Museum Archives, July 19, 1988.
} 
jewelry and weavings for sale in the gallery. Many of her patrons for both colcha embroideries and rug refurbishment came from people who frequented the gallery or exhibited there.

Frances also moved to Ranchos de Taos after Carson. Like Sophie, Frances continued to repair rugs and create new colcha embroideries. She also held stitching workshops and grew friendly with local gallery owners and museum personnel. Being very visibly associated with making colchas, Frances became much better known in these circles than Sophie. Even in the early nineties when Helen Lucero, curator at Santa Fe's Museum of International Folk Art, and I interviewed Frances, there was no mention of what Sophie was doing then. Helen never asked, and I wrongly assumed by that time Sophie was no longer making colcha embroideries. ${ }^{5}$

Elmer Shupe, his partners and brothers-in-law, promoted an art form geared for tourists and collectors that drew upon symbolic resources of local indigenous groups and the heritage of Southwestern weaving. Their intent was to reduce these neo-traditional elements or ethnic emblems to simple forms with immediate visual and semantic impact. Writing of legitimacy and reproduction in the 1930s, Walter Benjamin states that authenticity of an art work "has its basis in ritual" and "in traditional use." ${ }^{16}$ The Carson enterprise reproduced textiles that not only portrayed history and ethnicity, but also appropriated the trappings of ritual and indigenous subject matter, thus capitalizing on touristic expectations of an authentic souvenir of the "West" by transforming authenticity into the subject of art - not the source of traditional practice and ceremony, but the aesthetic measure of legacy.

Carson colcha embroideries were much too big to use embroidery hoops for stretching the ground fabric. So, stitchers tacked the ground fabric onto large plywood boards in order to have a firm backing. This is evident in the photograph from Frances Graves's family collection of photographs. Sophie's son, Tony Graves, has also described this common process of working off a board - whether stitching or repairing rugs and, how he as a child helped stitch over the ground fabric. ${ }^{7}$ Just below Frances's colcha embroidery-in-progress, is a drawing by Frances of a horse, which she first drew on newsprint and then transferred to the ground cloth by converting it into a stencil. The image on the right shows one of Sophie's large colcha embroideries in progress. The basic design was drawn freehand on the foundation fabric (probably monk's cloth), and then embroidered over to obscure any pencil or marker lines.

\footnotetext{
${ }^{5}$ Interview with Frances Graves by Helen Lucero and author, August 14, 1991.

${ }^{6}$ Butler, Beverley. "Heritage and the Present Past," in Handbook of Material Culture. Edited by Christopher Tilley et al. London: Sage Publications, 2006, 468.

${ }^{7}$ Interview with Tony Graves by author, Taos, New Mexico, August 6, 2019.
} 


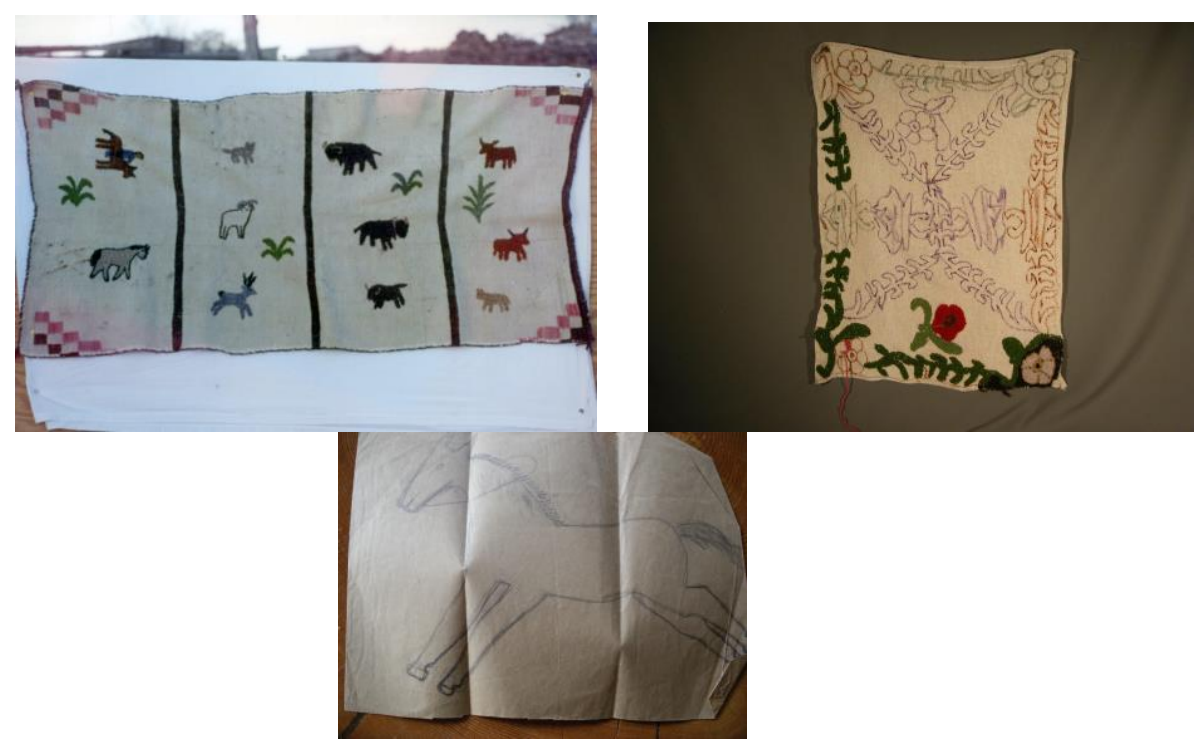

(L) Frances Graves, colcha embroidery in progress tacked to plywood board, 1970s-1980s. (C) Frances's drawing pattern. Frances Graves's family collection. Permission granted.

(R) Sophie Graves, colcha embroidery under drawing, late 1980s. Courtesy of the Millicent Rogers Museum, Taos, New Mexico.

In the next set of images, Sophie's bird in the detail on the left is more whimsical and idiosyncratic than the birds in Frances's composition. As evidenced by Valerie Graves's colored drawing, family members often consulted about color choices and drew designs for each other. Valerie Graves was one of Frances's daughters-in-law at the time of the creation of this piece. Bonnie Ryan, Sophie's daughter, also drew for her mother, and helped plan compositions. In terms of favorite motifs, Sophie and Frances loved to feature birds. There are several series of "Dickey" birds done by both sisters using a similar color palette of blue hues. These birds are probably derived from bird motifs on Indian chintzes first imported into the Spanish colonies in the sixteenth and seventeenth centuries. Another cross-influence could have come from the image of the distelfink, a popular bird design featured in Pennsylvania Dutch repertoire and rendered in crewel needlework, which came to the Southwest over the Santa Fe Trail in the late nineteenth century. Whatever the source (possibly magazine illustrations), bird designs gave Sophie and Frances a lot of pleasure and they often reproduced them. Bird compositions were another instance where Sophie's colchas were indistinguishable from Frances's. 


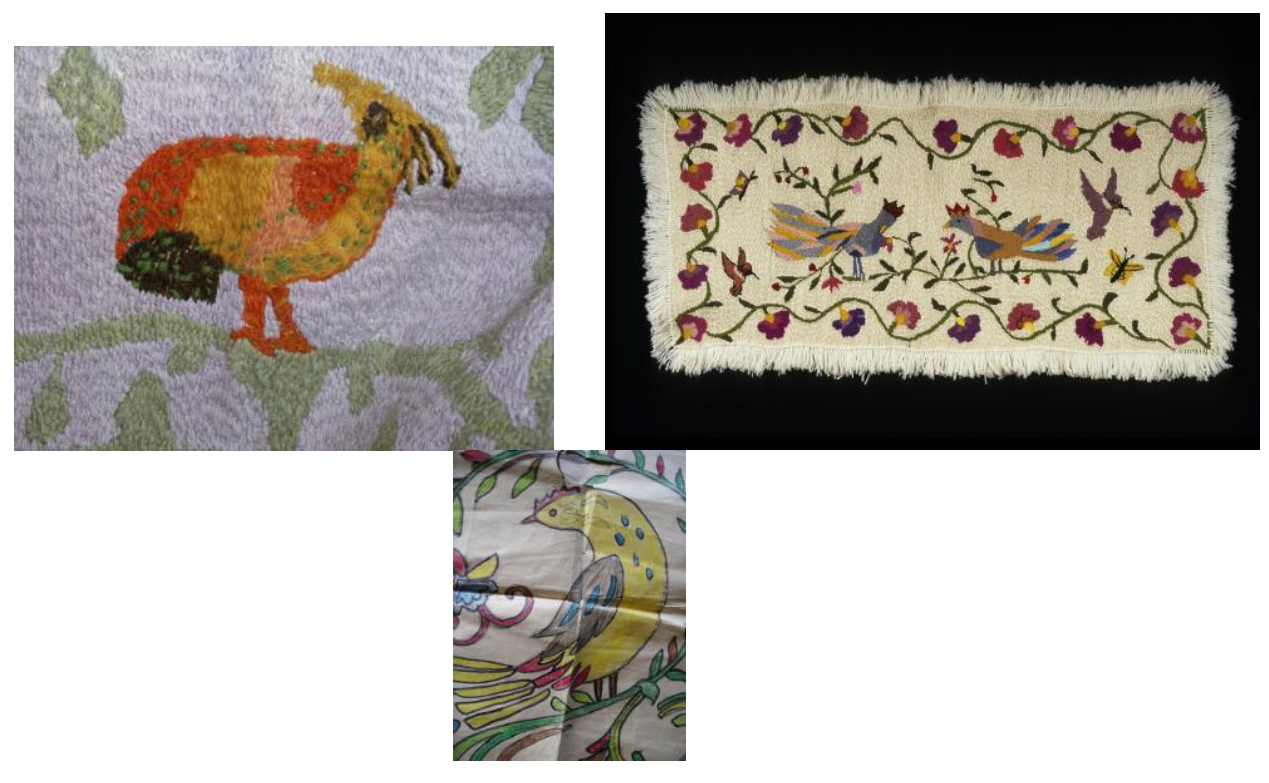

(L) Sophie Graves "Bird” (detail), n.d. Photo by author.

(R) Frances Graves "Birds," n.d. Private collection. Permission granted.

Drawing by Valerie Graves for Frances Graves, n.d. Frances Graves's family collection. Permission granted.

Bonnie Ryan took the initiative to enter her mother's colcha in a county fair competition in the late 1980s where Sophie earned a blue ribbon. Compared to Frances's Southwestern style colcha on the right, which was used to represent her artistry as a NEA National Heritage Fellow in 1994, Sophie uses non-traditional ovals and large areas of vibrant color punctuated with exotic plant forms. Her work was intensely coloristic and more experimental than Frances's many variations on Southwestern themes of flora and fauna.
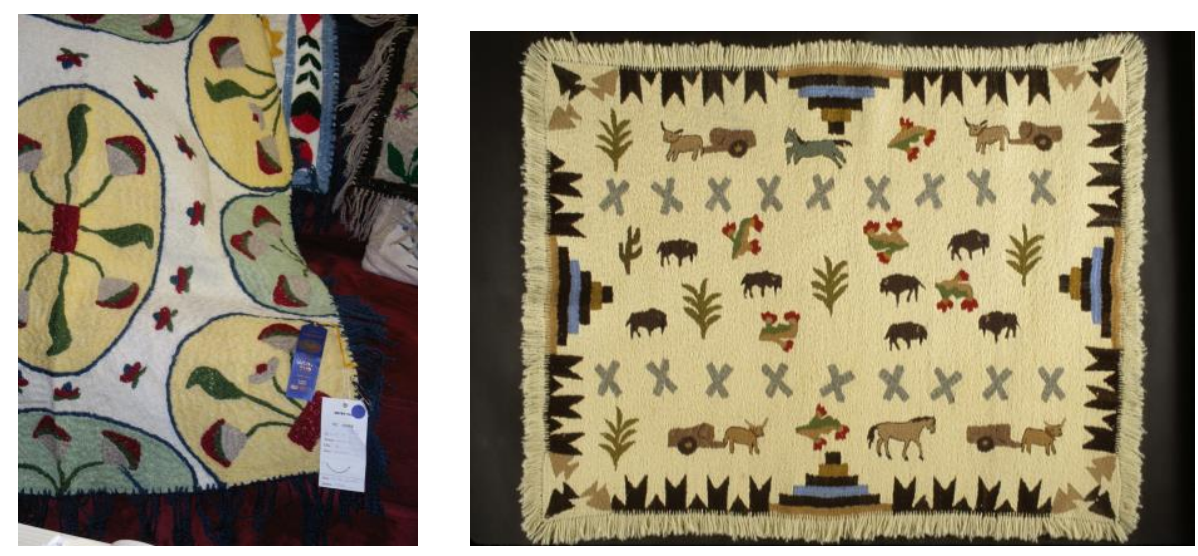

(L) Sophie Graves, prize-winning colcha embroidery, 1980 s (permission from Sophie Graves's family). (R) Frances Graves, 'Blue Pony," colcha embroidery, 1990 used to publicize NEA National Heritage Fellowship in 1994, private collection (permission granted).

As the years passed, Frances continued to attract the critical attention of patrons and museum professionals, who collected her work and also wrote about her. Sophie's creative energy went into supporting her family with her textile work, and sustaining them financially. Frances was adept at self-promotion and cultivating numerous friendships through her art. Sophie was no less passionate about art making, but less inclined to publicize her artistic efforts outside her circle of 
friends and family. Although both sisters, along with other relatives, are credited with creatively inventing the Carson colcha style, it was Frances Graves, through the public attention given to her colcha embroideries, who eventually came to epitomize it.
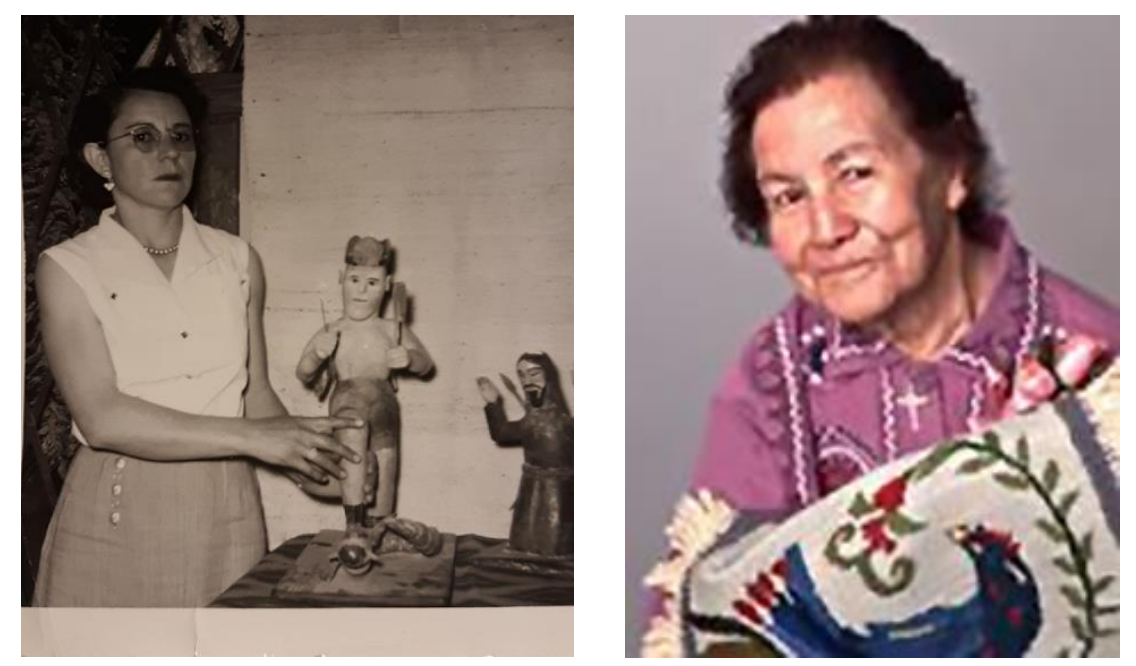

Sophie Graves (L), probably 1960s, Sophie Graves Family Collection. Permission granted. Frances Graves on right, 1990s. Private collection. Permission granted.

\section{Bibliography}

Butler, Beverley. "Heritage and the Present Past," in Handbook of Material Culture edited by Christopher Tilley et al., London: Sage Publications, 2006, 463-479.

Interview with Lisa A. Cordova by author, Taos, New Mexico, August 7, 2019.

Interview with Frances Graves by Helen Lucero and author, Taos, New Mexico, November 17, 1991.

Interview with Louise and Tony Graves by author, Taos, New Mexico, August 6, 2019.

Interview with Sophie Graves by Shelby Tisdale, Millicent Rogers Museum Archives, Taos, New Mexico, July 19, 1988.

Interview with Bonnie Ryan by author, Taos, New Mexico, October 5, 2012.

Lippard, Lucy. "Busywork: The Real Thing" in Textiles, Community and Controversy edited by Jools Gilson and Nicola Moffat, London: Bloomsbury Visual Arts 2019, 46-57,

MacAulay, Suzanne. Stitching Rites: Colcha Embroidery Along the Rio Grande. Tucson, Az: The University Press of Arizona, 2000. 